\title{
Day Times Mole per Liter per Meter Squared
}

National Cancer Institute

\section{Source}

National Cancer Institute. Day Times Mole per Liter per Meter Squared. NCI Thesaurus.

Code C111180.

Days times moles per liter, divided by meters squared. 